\title{
STRATEGI DESTINATION BRANDING WADUK JATILUHUR SEBAGAI WISATA AIR UNGGULAN DI JAWA BARAT
}

\author{
Sophia Novita ${ }^{1}$, Firmansyah ${ }^{2}$ \\ Fakultas Ilmu Komunikasi, Universitas Islam Bandung \\ Universitas Islam Bandung \\ sophianovita93@gmail.com ${ }^{1}$, fimansyah.ivan272@gmail.com²
}

Received: November 19, 2020; Revised: February 9, 2020; Accepted: February 27, 2021

\begin{abstract}
Abstrak
Pariwisata merupakan sektor penyedia jasa yang mengoptimalkan potensi kawasan wisata. Di Indonesia, pariwisata ditetapkan sebagai leading sector dan core economy. Pariwisata memberikan kontribusi besar pada lapangan pekerjaan, devisa negara dan juga mendukung kemajuan daerah melalui pemasukan PAD (pendapatan asli daerah). Hal tersebut juga menjadi fokus Pemerintah Jawa Barat, dalam Rencana Induk Pembangunan Kepariwisataan Provinsi tahun 2015-2025 terdapat aturan mengenai wisata unggulan untuk kawasan destinasi berbasis air. Salah satu kawasan yang memiliki potensi mengenai hal itu adalah Waduk Jatiluhur di Kabupaten Purwakarta. Kawasan yang sebelumnya dipergunakan sebagai PLTA kini diubah menjadi tujuan wisata dengan cara membranding kawasan tersebut. Untuk mengetahui strategi branding yang dilakukan maka penelitiann ini dianalisa melalui teori strategi destination branding dari Morgan \& Pritchard. Dengan penelitian metode kualitatif studi kasus. Hasil temuan memperlihatkan bahwa ada lima tahapan dalam melakukan branding destinasi wisata yang dilakukan oleh pemerintah dan masyarakat. Tahap pertama, menetapkan nilai-nilai inti dari tujuan dan mereknya melalui pemetaan pasar. Tahap kedua, mengembangkan identitas merek dengan empat daya tarik buatan yang dimaksimalkan pemerintan. Tahap ketiga, mengenalkan produk kepada masyarakat melalui event olahraga bertaraf internasional salah satunya The 1st Jatiluhur Stand Up Paddle and Kayak Exhibition bertajuk "Green Water Life". Tahap keempat, dengan imlementasi brand melalui simbol, slogan dan membuat aplikasi bernama "Sampurasun". Tahap kelima, monitoring dan evaluasi yang dilakukan oleh tim media sosial dan Pokdarwis. Temuan ini Memperlihatkan bahwa upaya branding destinasi tidak hanya menjadi tanggung jawab pemerintah tetapi masyarakat sekitar. Temuan lainnya ialah bahwa ada beberapa daya tarik buatan yang sengaja dijadikan strategi pada branding destinasi ini.
\end{abstract}

Kata Kunci: Branding, Destinasi, Waduk Jatiluhur, Purwakarta 


\begin{abstract}
Tourism is a service provider sector that optimizes the potential of tourist areas. In Indonesia, tourism is defined as the leading sector and core economy. Tourism provides a major contribution to employment, foreign exchange and also supports regional progress through the income of PAD (local revenue). This is also the focus of the West Java Government, in the 2015-2025 Provincial Tourism Development Master Plan, there are regulations regarding leading tourism for water-based destination areas. One area that has the potential for this is the Jatiluhur Reservoir in Purwakarta Regency. The area that was previously used as a hydropower plant has now been transformed into a tourist destination by comparing the area. To find out which branding strategy is being carried out, this research analyzes it through the theory of destination branding strategy from Morgan \& Pritchard. With a qualitative case study method research. The findings show that there are five stages in branding tourist destinations carried out by the government and the community. The first stage, establishing the core values of the goals and the brand through market mapping. The second stage, developing a brand identity with four artificial attractiveness that is maximized by the government. The third stage, introducing the product to the public through international sporting events, one of which is The 1st Jatiluhur Stand Up Paddle and Kayak Exhibition entitled "Green Water Life". The fourth stage, with the implementation of the brand through symbols, slogans and creating an application called "Sampurasun". The fifth stage, monitoring and evaluation carried out by the social media team and Pokdarwis. These findings show that destination branding efforts are not only the responsibility of the government but the surrounding community. Another finding is that there is some artificial appeal that is deliberately used as a strategy for branding this destination.
\end{abstract}

Keywords: Branding, Destination, Jatiluhur Reservoir, Purwakarta

\section{Pendahuluan}

Pariwisata telah ditetapkan sebagai sektor unggulan dan core economy di Indonesia. Industri pariwisata juga mendukung kemajuan daerah melalui pemasukan PAD (pendapatan asli daerah), hal tersebut telah dibuktikan oleh Kabupaten Belitung melalui pengembangan Kawasan Ekonomi Khusus (KEK) Tanjung Kelayang, PAD di Belitung meningkat 300\% selama 4 tahun. Hal ini disebabkan oleh kunjungan wisatawan melonjak sehingga dampak perekonomian pun kian dirasakan masyarakat (Reisha, 2019). $\begin{array}{lrr}\text { Hal inilah yang } & \text { membuat } \\ \text { pemerintah } & \text { harus } & \text { terus } \\ \text { mengembangkan sektor } & \text { pariwisata } \\ \text { yang dimilikinya. } & \text { Karena }\end{array}$ mengembangkan potensi di setiap daerah, dapat menjadikan aspek destinasi pariwisata yang menguntungkan (Kusuma, 2018). Inilah yang juga dikembangkan oleh Kabupaten Purwakarta saat ini, Purwakarta berupaya bertransformasi dari daerah persinggahan menjadi daerah tujuan wisata.

Provinsi Jawa Barat merupakan daerah dengan akses jalur 
hidrologi terbesar di Indonesia karena berlimpah irigasi, waduk, sungai dan danau. Untuk memunculkan potensi tersebut, maka Pemerintah Provinsi dan Pemerintah daerah Jawa Barat bersama Perum Jasa Tirta (PJT) II bekerjasama untuk mengembangkan sektor pariwisata air sebagai unggulan. Dengan begitu, jalur hidrologi punya nilai tambah karena tak hanya digunakan sebagai sumber air baku dan pertanian.

Sejalan dengan Peraturan Daerah No 15 tahun 2015, tentang rencana induk pembangunan Kepariwisataan Provinsi Jawa Barat tahun 2015-2025, di dalamnya terdapat peraturan mengenai wisata unggulan untuk kawasan destinasi berbasis air, dan daerah di Jawa Barat yang memiliki potensi cukup besar mengenai hal tersebut ialah Waduk Jatiluhur yang diresmikan pada tahun 1967.

Waduk Jatiluhur merupakan bendungan/waduk terbesar yang ada di Indonesia. Bendungan Waduk Jatiluhur yang mulai di bangun pada tahun 1957 kontraktor asal Prancis Compagnie française d'entreprise ini memiliki potensi air sebesar 12,9 miliar m3 /tahun, dan juga sebagai waduk serbaguna pertama di Indonesia.

Sebagai upayanya dalam memajukan pariwisata, maka dibutuhkan usaha yang terintegrasi dan strategies, sehingga brand memiliki peran penting dalam mencitrakan sebuah destinasi pariwisata dan menjadi salah satu indikator penting dalam menentukan keberhasilan dan citra sebuah daerah pariwisata (Maulida,2019). Fungsi waduk Jatiluhur selain sebagai Pembangkit Listrik Tenaga Air (PLTA) juga sebagai sektor perekonomian berbasis air tawar, banyak masyarakat Jatiluhur yang mendapatkan manfaat dari waduk tersebut. Dalam penelitian Eksternalitas Waduk Jatiluhur Bagi Masyarakat Kecamatan Jatiluhur Kabupaten Purwakarta (Kusumah \& Amaliah, 2015), keberadaan waduk Jatiluhur memberikan eksternalitas positif bagi masyarakat Kecamatan Jatiluhur. Hal ini terjadi karena keberadaan waduk Jatiluhur memberikan banyak manfaat positif bagi kehidupan mereka, mulai dari keberadaan PLTA yang memenuhi kebutuhan listrik sehari-hari, sarana hiburan dan juga penginapan.

Pada penyelengaaran Asian Games tahun 2018 waduk Jatiluhur dipilih sebagai venue untuk perlombaan dayung dan pada perhelatan olahraga se-Asia. Pemanfaatan waduk Jatiluhur sebagai lokasi perlombaan mendapat banyak atensi dari berbagai pihak terutama para atlet yang mengikuti pertandingan. Hal tersebut menjadi perhatian pemerintah daerah untuk melakukan pengembangan karena potensi pariwisata yang cukup besar.

Namun Potensi wisata pada waduk Jatiluhur tidak akan berkembang tanpa adanya branding yang baik. Pemasaran destinasi tidak bisa disamakan dengan pemasaran produk dan jasa lainnya, hal itu karena adanya keunikan dari suatu destinasi sehingga harus menjadi pertimbangan dalam mengembangkan strategi pemasaran suatu destinasi khususnya untuk keberhasilan merek suatu destinasi (Emrizal, 2016). Apabila penetapan branding tidak sesuai dengan karakteristik tempat tersebut maka akan menjadi boomerang bagi destinasi tersebut. Maka dalam hal ini diperlukan perencanaan mengenai destination branding agar bisa menarik wisatawan maupun menjadi alat komunikatif untuk 
mempromosikan tempat tersebut (Michandani, 2019).

Upaya branding destinasi yang pernah dilakukan oleh kota Purwakarta, dalam hasil penelitian (Benedita \& dkk, 2018) menunjukkan branding Kabupaten Purwakarta dengan tagline "Purwakarta Berkarakter", telah membentuk karakter budaya Sunda yang kuat di masyarakatnya. Pemerintah daerah secara sistematis melakukan branding daerahnya sebagai daerah yang memiliki karakter tersendiri di Jawa Barat. Pemerintah Kabupaten Purwakarta kemudian melakukan rebranding dengan "Purwakarta Istimewa" dengan filosofi sebagai daerah yang mengistimewakan masyarakatnya melalui pelayanan yang diberikan pemerintah daerah, mulai dari pendidikan, kesehatan, pembangunan hingga budaya melalui sembilan kebijakan pembangunan.

Sejalan dengan pentingnya sebuah brand dalam sektor pariwisata, maka kawasan Waduk Jatiluhur yang sebelumnya merupakan PLTA dan kini mulai di branding menjadi destinasi tujuan wisata dengan menggelar berbagai kegiatan di lokasi tersebut. Kepala Disbudpar Jawa Barat juga mengungkapkan bahwa Waduk Jatiluhur dirancang untuk destinasi wisata berbasis sport tourism. Seperti dengan diadakannya "The 1st Jatiluhur Stand Up Paddle \& Kayak Exhibition 2019 di Waduk Jatiluhur", dengan tujuan memperkenalkan wisata waduk Jatiluhur sebagai wisata air. Acara The 1st Jatiluhur Stand Up Paddle and Kayak Exhibition sukses terselenggara dan dirasakan pemerintah daerah meraih banyak perhatian para wisatawan. Selain itu, ada kegiatan internasional lainnya seperti The 1st International Jatiluhur Jazz Festival 2019. Festival jazz ini dinilai efektif mempromosikan Jatiluhur pada taraf internasional dan mampu meningkatkan kunjungan mancanegara, untuk wisata halal akan dibuat masjid dan hotel terapung di tengah waduk.

Penelitian sebelumnya oleh (Richelieu,2018) mengenai A sportoriented place branding strategy for cities, regions and countries dalam temuannya menunjukan bagaimana sebuah kota, wilayah atau negara bisa berhasil dalam usahanya menggunakan olahraga untuk memasarkan dirinya ke luar negeri. Maka dari itu setiap destinasi harus memunculkan sebuah keunikan agar upaya brandingnya berjalan dengan berhasil. Penelitian lainnya oleh (Maruto,2020) mengenai kampung lawang seketeng yang membranding kampung tersebut dengan memberi sebutan Kampung Heritage dan kampong wisata kuliner, hal ini merupakan perpaduan untuk meningkatkan jumlah pengunjung dari potensi wisata kuliner yang dimiliki. Hal tersebut merupakan langkah branding bagi pengelola untuk terus meningkatkan dan menarik perhatian pengunjung. Dalam penelitian lain (Michandani, 2019) dibahas mengenai perancangan destination branding desa wisata Kerta di Kecamatan Payangan Kabupaten Gianyardari temuannya lebih menekankan branding destinasi melalui visual. 
Hasil temuannya ialah bahwa desain logo Desa Wisata Kerta sebagai Desa Iklim digambarkan dengan empat komponen yakni bambu, sapi, manusia dan pura. Penelitian ini lebih menekankan pada konsep kreatif sebagai cara untuk menyampaikan pesan dari perancangan identitas brand Desa Wisata Kerta melalui media komunikasi visual.

Berdasarkan pada penelitian terdahulu terlihat bahwa penelitian yang ada membahas mengenai destination branding melalui satu keunikan wisata, akan tetapi untuk kawasan waduk Jatiluhur ini, terdapat empat daya tarik wisata buatan dengan tahapan strategi branding yang berbeda-beda, terdiri dari sport tourism, cultural tourism, culinary tourism dan halal tourism. Selain itu pandangan masyarakat tentang waduk juga menjadi salah satu permasalahan yang dihadapi bagi sebagian masyarakat, waduk hanya sekedar bendungan biasa dan tidak dijadikan sebuah destinasi khusus untuk berwisata, bahkan belum banyak orang yang mengenal Waduk Jatiluhur sebagai tujuan wisata padahal potensi perkembangan wisata di daerah tersebut sangat besar, oleh sebab itu event-event yang telah dibuat merupakan upaya yang telah dilakukan pemerintah untuk lebih mengenalkan destinasi Jatiluhur menjadi objek wisata dalam persepsi masyarakat. Dalam (Rahman, 2017), dikatakan bahwa destination branding mampu merubah persepsi turis dari negatif ke postif, dengan dukungan fasilitas wisata yang sesuai dengan kebutuhan pengunjung untuk memberikan kemudahan dan memenuhi kebutuhan mereka selama berkunjung.

Persoalan dalam penelitian ini mengindikasikan bahwa ada beberapa upaya dalam mengubah image sebuah kawasan, yaitu dengan membranding destinasi menggunakan daya tarik yang ada pada kawasan tersebut. Branding merupakan bentuk komunikasi yang dimanfaatkan sebagai pembeda sebuah produk. Dalam destination branding waduk Jatiluhur yang dibedakan adalah kekhasan wisata air dengan mempopulerkan berbagai daya tarik wisata yang ada didalamnya, untuk mengubah image kawasan PLTA menjadi kawasan wisata.

Berdasarkan pada permasalahan tersebut penelitian ini berupaya menggambarkan proses branding yang dilakukan pemerintah Provinsi Jawa Barat dalam membangun branding sebuah kawasan wisata. Beberapa hal yang penting yang menjadi persoalan dalam penelitian ini, yaitu tahapan strategi apa saja yang dilakukan dan proses yang dijalannkan di masingmasing daya tarik.

Penelitian ini dilakukan untuk menjelaskan bagaimana Pemerintah Provinsi Jawa Barat beserta Pemerintah Daerah melakukan upaya branding sebagai langkah mengubah image sebuah kawasan yang sebelumnya hanya digunakan untuk fasilitas Pembangkit Listrik tenaga Air atau (PLTA) menjadi kawasan 
tujuan wisata unggulan berbasis air bertaraf internasional, yang mampu menarik perhatian para wisatawan. Serta bagaimana proses tahapan komunikasi yang dilakukan dari tiap tahapan tersebut.

\section{Kerangka Teori}

Teori yang digunakan dalam menganalisis penelitian ini ialah melalui tahapan strategi destination branding menurut Morgan \& Pritchard, teori ini menjelaskan bahwa arsitektur merek atau brand harus mencerminkan semua komponen kunci dari destination branding, termasuk posisi, manfaat (pikiran/logika) rasional dan emosional (perasaan) dan asosiasi, bersama dengan kepribadian mereknya.

Destination branding merupakan proses yang digunakan untuk mengembangkan identitas unik dan kepribadian yang berbeda dari semua destinasi yang kompetitif. Tujuan branding yaitu "memilih campuran elemen merek yang konsisten untuk mengidentifikasi dan membedakan tujuan melalui pembangunan citra positif" (Cai, 2000).

Teori dari Destination branding dalam penelitian ini merupakan upaya untuk untuk mengubah persepsi atau pandangan seorang terhadap suatu tempat atau tujuan termasuk dalam melihat perbedaan sebuah tempat untuk dipilih sebagai tujuan wisata.

Arsitektur merek pada intinya dalam blueprint harus memandu pembangunan merek, pengembangan dan pemasaran, yang merupakan perangkat yang dapat digunakan oleh semua pemasar destination branding. Morgan \& Pritchard (2004 : 69) menyarankan lima tahap untuk melakukan destination branding yakni:

1. Market investigation and strategic analysis

Tahapan ini ialah melakukan kegiatan riset, pemetaan potensi pasar, hal-hal apa saja yang dapat dikembangkan serta menyusun strategi yang tepat untuk mengembangkan destinasi. Hal tersebut menunjukan bahwa fungsi sebuah kegiatan investigasi pasar dan strategi pasar adalah untuk menyusn berbagai langkah dan strategi yang bisa dilakukan untuk melakukan pengembangan destinasi tersebut.

2. Brand identity development $\begin{array}{lr}\text { Setelah } & \text { melakukan } \\ \text { penginvestigasian, maka tahap } \\ \text { selanjutnya } \\ \text { mengembangkan }\end{array}$ Identitas merek seperti apa yang ingin dimunculkan dari destinasi tersebut, dalam hal ini perlu kejelasan dari visi-misi destinasi, sehingga nantinya citra yang terbentuk berdasarkan hasil identitas yang dimiliki oleh destinasi. Langkah atau upaya yang bisa dilakukan adalah dengan melakukan sebuah riset, atau juga bisa melihat dari potensi utama yang dimiliki dari destinasi yang ada.

Dalam hal ini, Panduan gaya desain merek harus memastikan konsistensi pesan dan pendekatan agar memperkuat nilai-nilai merek. Visi (yang dibagikan) harus dinyatakan dengan jelas dalam nilai-nilai inti merek secara konsisten dan diperkuat melalui produk dan semua bentuk komunikasi pemasaran. Untuk menjadi sukses dalam menciptakan keterikatan emosional destintation branding 
harus: 1) kredibel, 2) mudah disampaikan, 3) membedakan dengan merek lain, 4) dapat menyampaikan ide-ide yang kuat, 5) menyenangkan bagi para pemangku kepentingan dan mitra, 6) beresonansi dengan konsumen. Identitas merek atau branding identity sebagai wisata air tidaklah cukup untuk membangun merek yang kuat. Kotler \& Keller (2006) menjelaskan bahwa brand Identity atau identitas merek adalah seperangkat asosiasi merek yang unik yang diciptakan oleh para penyusun strategi merek. Asosiasi-asosiasi ini mencerminkan kedudukan suatu merek dan merupakan suatu janji kepada pelanggan dari anggota organisasi. Identitas merek akan membantu kemantapan hubungan diantara merek dan pelanggan melalui proposisi nilai yang melibatkan manfaat fungsional, manfaat emosional atau ekspresi diri.

3. Brand introduction

Langkah selanjutnya adalah memperkenalkan brand. Brand launch dapat dilakukan melalui berbagai media sebagai berikut, media relations seperti advertising, direct marketing, personal selling, website, brochures, atau event organizer, film- makers, destination marketing organization (DMOs) serta journalist. Tahapan ini merupakan tahap mengkomunikasikan brand melalui berbagai media yang tersedia.

Dalam mengenalkan produk sebuah destinasi tidak sama dengan pengenalan produk lainnya, perlu langkah-langkah yang tepat agar pengenalan destinasi wisata tidak menimbulkan persepesi atau image yang negatif di masyarakat. Pengenalan destinasi wisata pun harus membuat masyarakat tertarik untuk berkunjung dan menjadi wisatawan potensial. Karena itulah, pengenalan brand kepada masyarakat sebagai wisatawan potensial, harus menjadi unik dan berbeda dengan yang lain.

4. Brand implementation

Brand adalah sebuah janji. Semua pihak- pihak yang terlibat mulai dari pemerintah, pihak hotel, travel agensi, masyarakat setempat harus berusaha mewujudkan janji yang diucapkan. Sehingga wisatawan yang datang akan merasa betah dan terkesan dengan daerah tujuan. Bebrapa kasus yang biasanya terjadi adalah ketika wisata alam sudah sangat indah tapi tidak didukung dengan kebersihan tempat umum seperti toilet dan tempat beribadah. nimbulkan pungli (pungutan liar) dan meresahkan wisatawan.

5. Monitoring and evaluation

Tahap terakhir ini adalah sebuah usaha untuk memantau apakah ada penyimpangan, kekurangan dan sebagainya dari apa yang telah dilakukan. Hasil monitoring tersebut kemudian dievaluasi dan direview untuk perbaikan selanjutnya.

\section{Metode Penelitian}

Penelitian ini menggunakan metode kualitatif studi kasus. Kirk dan Miller dalam Moleong (2004: 3) mendefinisikan penelitian kualitatif sebagai sebuah tradisi yang ada dalam pengetahuan ilmu sosial yang bergantung dalam diri manusia itu. 
Oleh sebab itu metode ini dipilih untuk mengambarkan sekaligus mendeskripsikan fakta dan data yang ada pada objek kawasan waduk Jatiluhur.

Data dalam penelitian ini
diperoleh melaui wawancara,
observasi serta kajian pustaka yang
terkait dengan penelitian. Wawancara dilakukan kepada Kepala Dinas Budaya dan Provinsi Jawa Barat, Dr. H. Dedi Taufik, M.Si. dan Sekretaris Dinas Pariwisata Kabupaten Purwakarta Heri Irawan untuk mengetahui bagaimana strategi dalam mengembangkan wisata unggulan berbasis air di waduk Jatiluhur. Observasi dilakukan secara partisipatif untuk mengetahui dan melihat situasi kawasan wisata waduk Jatiluhur. Kajian pustaka dilakukan melalui tinjauan terhadap tulisan berupa jurnal, artikel serta foto yang ada terkait dengan kawasan wisata waduk Jatiluhur.

Subjek penelitian ini adalah pemerintah daerah, baik pemerintah provinsi Jawa Barat maupun pemerintah Kabupaten Purwakarta. Dalam penelitian ini dikhususkan pada dinas pariwisata provinsi dan kabupaten sebagai pembinaan dan pengendalian kawasan wisata yang ada di Jawa Barat. Objek penelitian ini adalah kawasan wisata di waduk Jatiluhur yang menyajikan wisata berbasis air.

\section{Hasil Penelitian dan Pembahasan}

Coshall, Tapachai dan Waryszak (2000) dalam Morgan \& Pritchard (2004 : 66) menjelaskan bahwa citra sangat penting dan bagaimana sebuah tempat dapat menginspirasi orang untuk berkunjung dan mengunjungi kembali. Destination branding dapat membantu menjembatani kesenjangan antara kekuatan destinasi dan persepsi pengunjung potensial. Pemasar destinasi wisata harus menentukan bagaimana citra destinasi mereka bersaing dengan pesaing utama destinasi lainnya.

Proses destination branding waduk jatiluhur sebagai wisata air unggulan di Jawa Barat perlu melakukan beberapa tahap untuk mempromosikan destinasi wisata. Tahap pembentukan brand pada waduk jatiluhur sebagai destinasi wisata unggulan di Jawa Barat, dapat dilakukan dengan beberapa tahap strategi destination branding menurut Morgan \& Pritchard (2004 : 69) yaitu:

\section{Tahapan strategi branding Waduk Jatiluhur}
1) Market Investigation and Strategic Analysis

Tahap pertama dalam proses membangun destination branding adalah dengan menetapkan nilai-nilai inti dari tujuan dan mereknya. Kepala Dinas Pariwisata dan Kebudayaan Provinsi Jawa Barat, Dedi Taufik, dalam wawancara pada tanggal 19 Juli 2019 pukul 19.00 di kantornya menyebutkan bahwa Sektor pariwisata memberikan kontribusi besar pada Produk Domestik Bruto Nasional, devisa Negara dan lapangan pekerjaan. Dengan tujuan itulah Pemerintah saat ini sangat fokus pada pengembagan kepariwisataan. Pada tahun 2019, kementrian pariwisata menargetkan 257 juta wisatawan nusantara dan 20 juta wisatawan mancanegara, yang dua juta diantaranya ditargetkan berkunjung ke Jawa Barat. Alam Jawa Barat yang dikenal dengan sebutan gurilap yaitu gunung rimba lautan dan pantai sehingga memiliki potensi yang cukup besar sebagai tujuan destinasi wisata di Indonesia. 
Berdasarkan Peraturan

Daerah No 15 tahun 2015, tentang rencana induk pembangunan Kepariwisataan Provinsi Jawa Barat tahun 2015-2025 terdapat peraturan mengenai wisata unggulan untuk kawasan destinasi berbasis air. Salah satu daerah di Jawa Barat yang memiliki potensi cukup besar mengenai hal tersebut ialah waduk Jatiluhur yang terletak di Kabupaten Purwakarta

Kita melihat keberminatan kunjungan wisata berminatan ini kan hampir $35 \%$ berbasis alam dan kemudian $60 \%$ berbasis kebudayaan atau religi dan $5 \%$ itu berbasis buatan. Dari $35 \%$ kita breakdown lagi ada yang berbasis untuk pegunungan atau gurilap, jawabarat dikenal dengan gurilap yaitu gunung rimba lautan dan pantai nah itu sebagian disitu ada air kan. Dan juga kita punya beberapa danau besar, yang pertama itu ada danau jatiluhur (danau buatan) kemudian cirata, saguling dan juga jati gede ada empat danau ini. Kemudian juga selain danau ini mensuplai air khususnya untuk air minum yang menjadi intinya di ibu kota karena yang sumber air ibu kota adalah jati luhur untuk air minumnya, intiknya itu ada di kali malang selain mereka memberikan suplai energi untuk tenaga listrik kemudian juga untuk air minum, nah kenapa tidak kita lakukan untuk wisata yang memang berbasis sport tourism. (wawancara

Kadisparbud Provinsi Jawa Barat, Dedi Taufik, 19 Juli 2019 pukul 19.00)

Potensi wisata air di Jawa Barat yang memiliki sedikit wisata dalam bentuk danau membuat waduk Jatiluhur menjadi destinasi wisata potensial di Jawa Barat. Lokasi strategis waduk jatiluhur yang berada di Kabupaten Purwakarta terletak diantara Jakarta dan Bandung dapat menjadi alternatif wisata bagi masyarakat di dua kota besar tersebut. Purwatkarta pun merupakan kota persinggahan jalur mudik yang sering dilewati oleh para penduduk urban. Potensi ini yang menjadi salah satu alasan bagi pemerintah provinsi Jawa Barat untuk mengembangkan pariwisata dengan berbasis air. Menurut Kadisparbud Provinsi Jawa Barat, Dedi Taufik dalam wawancara, pengembangan wisata berbasis air di waduk jatiluhur berdasarkan pada kajian potensi wisata yang telah dilakukan pemerintah. Secara geografis, Jawa Barat tidak banyak memiliki wisata air selain wisata pantai, namun permintaan pasar wisatawan pada wisata air semakin meningkat. Contohnya adalah wisata air seperti waterboom selalu dipenuhi dengan pengunjung. Dengan adanya potensi permintaan pasar wisatawan domestik dan mancanegara untuk wisata air, maka pembangunan destinasi-destinasi wisata berbasis air menjadi salah satu pengembangan wisata yang diunggulkan di Jawa Barat. 


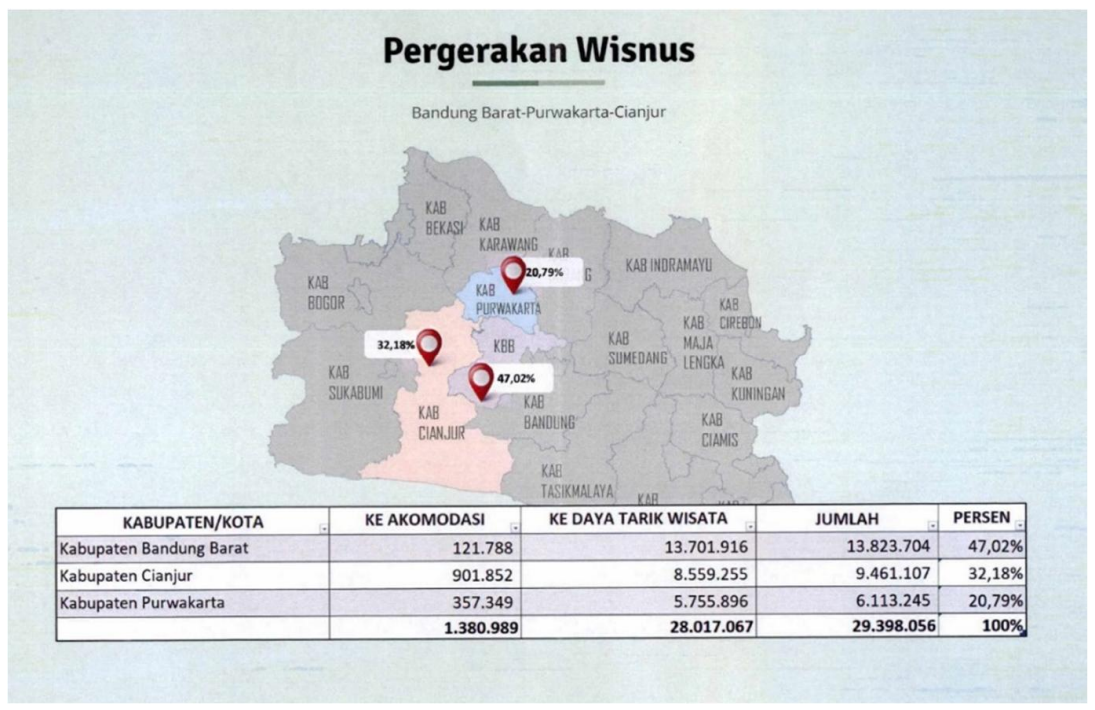

Gambar 1. Peta Pergerakan Wisatawan

Sumber: Dokumen Disparbud Jawa Barat (2019)

Morgan \& Pritchard (2004 : 70) mengungkapkan bahwa sangat penting untuk keberhasilan destination branding adalah sejauh mana destinasi tersebut memiliki kepribadian merek yang berinteraksi dengan target pasar. Branding harus kompleks dan kaya. Faktanya, merek yang paling kuat adalah mereka dengan identitas merek dan kepribadian terkaya. Namun kepribadian dan identitas merek yang kompleks cukup langka di dunia, atribut merek sering dibuat secara seadanya dan dangkal. Ciri-ciri branding seperti 'ramah', 'alami', dan 'kontemporer' sangat populer digunakakan, tetapi strategi branding seperti itu hampir tidak membantu untuk membangun merek yang menarik atau aspiratif. Wisata Air terbesar di Jawa Barat menjadi brand yang diperkenalkan oleh pemerintah provinsi Jawa Barat berdasarkan potensi pasar wisatawan bagi wisatawan domestik maupun wisatawan mancanegara.

Penentuan brand yang akan digunakan waduk jatiluhur sebagai destinasi wisata tidak mudah karena wisata waduk jatiluhur tidak banyak yang mengenal. Bila brand yang ditawarkan tidak spesifik dan secara khusus bahkan memiliki nilai (value) maka wisatawan akan sulit untuk tertarik. Pemetaan pasar wisatawan, khususnya di Jawa Barat, akan menentukan brand dan sub-brand apa yang akan digunakan pada destinasi wisata. Pemerintah provinsi Jawa Barat dan pemerintah Kabupaten Purwakarta telah melakukan pemetaan destinasi wisata untuk melihat potensi wisata berbasis alam, baik alami maupun buatan. Dalam pemetaan potensi wisata pada waduk jatiluhur, pemerintah daerah melakukan kajian dengan melakukan pemetaan destinasi wisata yang berintegrasi seperti waduk jatiluhur yang dapat diintegrasikan dengan wisata lainnya seperti wisata alam gunung parang. Wisata waduk Jatiluhur dikategorikan sebagai wisata primer atau wisata unggulan Jawa Barat 


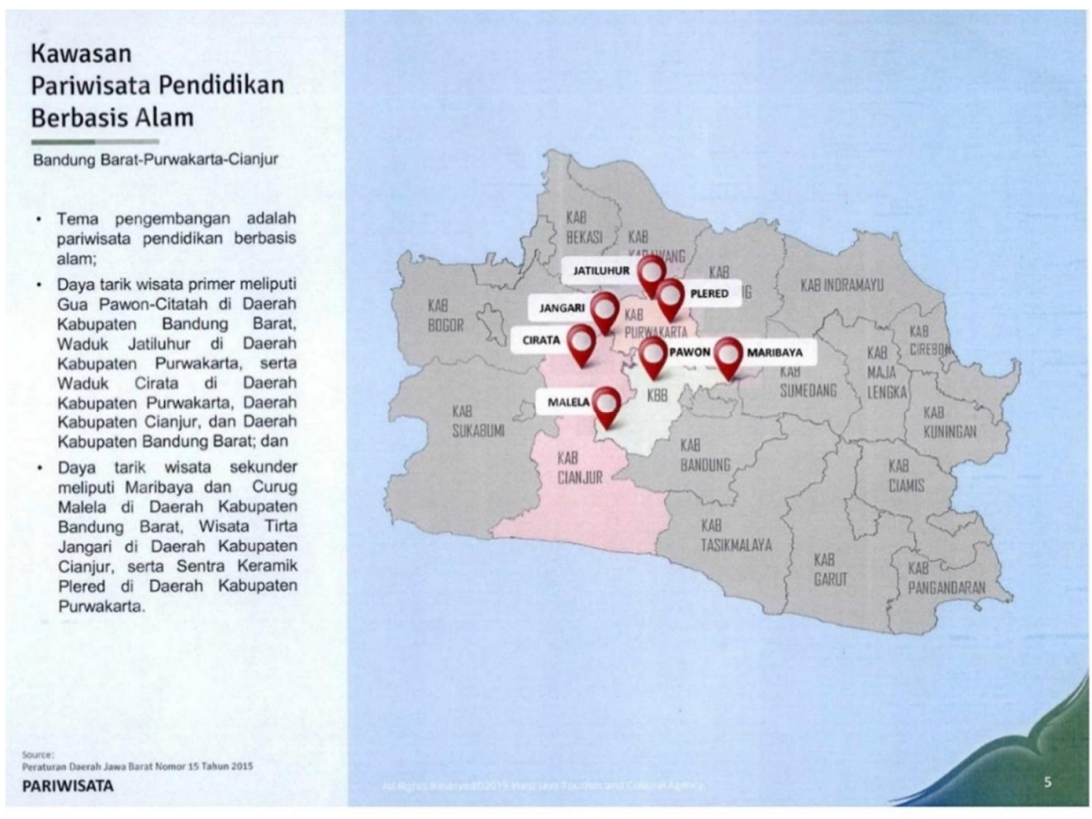

Gambar 2. Peta Potensi Wisata Alam Jawa Barat

Sumber: Dokumen Disparbud Jawa Barat (2019)

\section{2) Brand Identity}

Setelah investigasi pasar selesai, fase selanjutnya adalah mengembangkan identitas merek. Begitu nilai inti dalam merek telah ditetapkan, maka segala komponen identitas merek, dari fotografi, warna, tipografi dan nada harus dapat menginspirasi orang lain untuk berkunjung. Waduk Jatiluhur dengan potensi wisata air sebagai brand membangun destination branding yang memiliki value (nilai) untuk menarik pasar wisatawan, baik wisatawan domestik maupun wisatawan mancanegara. Menurut Morgan \& Pritchard (2004 : 70),

Untuk mengembangkan identitas merek (brand identity) pada tahap kedua destinasi wisata perlu memiliki daya tarik untuk menarik wisatawan datang. Suwardjoko Warpani dan Indira Warpani (2007) menjelaskan bahwa daya tarik wisata adalah segala sesuatu yang menjadi penyebab wisatawan mengunjungi daerah tertentu. Daya tarik wisata dapat berupa objek alamiah maupun binaan. Gunn

(1988:71) menyebutkan, keberagaman bentang alam dapat menjadi daya tarik wisata, sementara banyak peristiwa dan pertunjukkan - pada saat yang sama dapat menjadi daya tarik penunjang/tambahan, yang diperlukan adalah pemahaman, perencanaan, pengelolaan, dan program untuk memuaskan wisatawan. Peristiwa/atraksi, siapapun penyelenggaranya, tidak hanya ditujukan untuk mendatangkan, tetapi juga mengundang keterlibatan wisatawan.

Daya tarik wisata menurut Warpani (2007) adalah potensi alamiah atau binaan atau hasil rekayasa akal budi yang menjadi fokus pariswisara. Daya tarik wisara dapat pula diciptakan dengan merekayasa suatu objek dan/atau 
menawarkan "peristiwa" yang sesuai dengan potensi sumber daya daerah, keunikan peristiwa, serta sasaran dan kebutuhan pasar. Jenis daya tarik wisata dapat berupa potensi alam, potensi budaya, dan potensi manusia. Maka daya tarik ini yang menjadi nilai (value) yang dikembangkan untuk menarik wisatawan. Dalam penggambaran identitas merek atau brand identity yang ingin dibangun adalah dengan melakukan branding terhadap daya tarik wisata Waduk Jatilhur

Dalam kajian yang dilakukan pemerintah provinsi Jawa Barat, setidaknya ada empat daya tarik buatan yang akan dimaksimalkan pemerintah untuk menarik wisatawan, baik domestik maupun mancanegara. Beberapa jenis wisata yang ingin dibangun oleh pemerintah daerah merupakan wisata-wisata yang tetap berbasis air, sebagai identitas merek yang ditawarkan dalam wisata waduk Jatiluhur. Beberapa jenis daya tarik wisata buatan diantaranya adalah:

\section{a. Sport Tourism}

Secara historis, waduk jatiluhur sebelumnya juga dikenal sebagai destinasi olahraga air seperti olahraga ski air, mendayung, dan selancar angin. Weaver dan Lawton (2014: 28) menjelaskan ada beberapa alasan yang memenuhi syarat seorang wisatawan untuk mendatangi sebuah destinasi wisata. Salah satunya adalah pariwisata yang berhubungan dengan olahraga dengan melibatkan kegiatan atlet, pelatih dan lainnya yang terkait dengan kompetisi dan pelatihan. Para pengunjung wisata biasanya akan menghadiri acara olahraga dan lokasi yang berhubungan dengan event olahraga tertentu. Contohnya adalah Olimpiade dan Piala Dunia sepak bola tidak hanya memberikan sejumlah besar visibilitas pada tujuan tuan rumah dan tim yang berpartisipasi, tetapi juga melibatkan banyak peserta dan menghasilkan turis yang besar. Kompetisi olahraga dalam beberapa kasus juga telah digunakan untuk mempromosikan pemahaman lintas budaya dan hubungan damai antara negara dan budaya.

Sport tourism ini kan sangat bagus untuk tantangannya sangat menjanjikan dan kemudian yang masuk sport tourism biasaya turis-turis dari mancanegara, nah kami punya target kunjungan untuk tahun sekarang 48 juta itu adalah wisnus (wisatawan nusantara) kemudian juga 1,8 juta adalah untuk wisatawan mancanegara.

Kemarin sudah dilakukan yang namanya event paddle board yang skalanya nasional atau internasional, nah kemudian juga diharapkan nanti di tahun 2020 (wisatawan mancanegara). (wawancara dengan Kadisparbud Pemprov Jawa Barat Dedi Hidayat)

\section{b. Culture Tourism}

Kebudayaan Sunda menjadi satu karakteristik yang ditonjolkan pada branding Kabupaten Purwakarta. Branding tersebut juga diaplikasikan pada destinasi-destinasi wisata yang dilakukan pemerintah daerah. Wisata budaya menjadi daya tarik wisatawan yang menjanjikan terutama untuk wisatawan mancanegara yang tertarik pada budaya Indonesia. Daya tarik wisata budaya sunda

Nantinya kita mempromosikan budaya purwakarta, termasuk spot spot yang menjadi 
andalan purwakarta saat ini yaitu waduk jatiluhur, yang dijadikan primadonanya pak Gubernur hari ini di Jawa Barat untuk ke purwakarta, malahan beliau sudah menjanjikan, untuk kedepan anggaran pariwisata akan dinaikan berkali-kali lipat, Karena yang punya spot danau di jawa barat hanya beberapa kabupaten kota, sumedang, bandung barat, cianjur dan purwakarta. (wawancara dengan Sekretaris Dinas Pariwisata, Kebudayaan, Pemuda, dan Olahraga Kabupaten Purwakarta, Heri Anwar)

\section{c. Culinary Tourism}

Kabupaten purwakarta telah memiliki kuliner khasnya yakni sate maranggi. Potensi wisata kuliner ingin dikembangkan kembali oleh pemerintah Kabupaten Purwakarta terutama di kawasan Waduk Jatiluhur dengan mengembangkan wisata kuliner perikanan air tawar. Dalam perencanaan branding wisata kuliner tersebut, pemerintah menawarkan Restoran Terapung di tengah danau sebagai destinasi wisata yang dapat menarik wisatawan untuk menikmati hidangan ikan air tawar yang berbeda. Untuk menjangkau restoran terapung, wisatawan dapat menggunakan perahu milik warga dan menikmati pemandangan danau dari atas perahu.

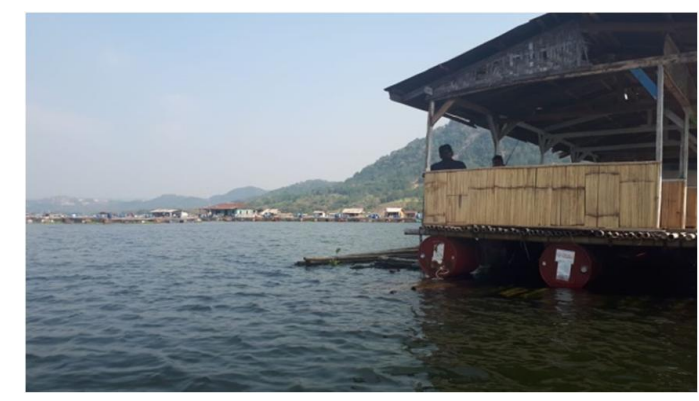

Gambar 3. Restoran Terapung Jatiluhur di Tengah Danau Sumber: Dokumentasi Peneliti (2019)

\section{d. Halal Tourism}

Jawa Barat masuk sebagai salah satu dari sepuluh destinasi wisata halal unggulan di Indonesia. Dikutip dari tulisan (Deny. 2019 dalam situs liputan6.com) disebutkan bahwa :

"Dalam beberapa tahun terakhir, pertumbuhan industri wisata halal di Indonesia menjadi yang terbesar di sektor pariwisata. Menurut data Kementrian Pariwisata RI, pertumbuhan industri wisata halal dunia pada 2018 menjadi yang terbesar dari sektor pariwisata dengan kunjungan

\begin{abstract}
wisatawan muslim mencapai 140 juta. Pembangunan infrastruktur sarana dan prasarana yang bersih dan nyaman seperti toilet Indonesia ditetapkan sebagai destinasi wisata halal (halal tourism) terbaik dunia 2019 standar Global Muslim Travel Index (GMTI) 2019 mengungguli 130 destinasi dari seluruh dunia.',
\end{abstract}

Wisata halal menjadi salah satu daya tarik wisatawan, terutama untuk wisatawan muslim. Dalam tren wisatawan, wisata halal menjadi salah 
satu alasan bagi wisatawan untuk berkunjung ke salah satu destinasi wisata. Hal tersebut dikarenakan destinasi wisata yang menawarkan wisata halal dapat dijamin akan kebersihan dan tempat ibadahnya. Pemerintah provinsi Jawa Barat memiliki strategi untuk meningkatkan pariwisata di daerahnya dengan menawarkan wisata halal sebagai sebuah daya tarik yang dapat membuat wisatawan domestik dan mancanegara untuk berkunjung. Pengembangan wisata halal atau moslem friendly dengan menawarkan destinasi wisata yang terjamin kebersihan dan pelayanannya seperti misalnya penyediaan toilet yang bersih yang ramah dengan wisatawan, pembangunan spot-spot toilet bersih dan ruang beribadah (mushala).

$\begin{array}{lr}\text { Wisata halal yang } \\ \text { dimaksud tidaklah seperti } \\ \text { yang banyak orang } \\ \text { pikirkan. Wisata halal } \\ \text { seakan-akan } & \text { adalah } \\ \text { wisata yang hanya } & \text { hatuk } \\ \text { diperuntukkan } & \text { untuk } \\ \text { muslim saja. Bukan } \\ \text { seperti itu, wisata halal } \\ \text { adalah bagaimana tempat } \\ \text { wisata itu memberikan }\end{array}$

pelayanan yang moslem friendly. Artinya apa, bahwa di lokasi wisata itu diberikan pelayanan kebersihan dan tempat ibadah yang memadai. Seperti toilet bersih, tempat istirahat yang nyaman, tempat ibadah mudah ditemukan. Dan itu bukan hanya ramah untuk muslim saja. Nantinya semua agama akan dibuat tempat ibadahnya di lokasi yang mudah dijangkau wisatawan. Jadi wisata halal itu menjadi lokasi wisata yang ramah untuk semua agama. (wawancara dengan Kadisparbud Pemprov Jawa Barat Dedi Hidayat)

Beberapa jenis daya tarik wisata buatan tengah dirancang oleh pemerintah provinsi Jawa Barat untuk menjadi bagian dari destination branding pada waduk jatiluhur. Daya tarik wisata tersebut menjadi bagian dari branding sebagai alasan dan motivasi wisatawan untuk mengunjungi Waduk Jatiluhur

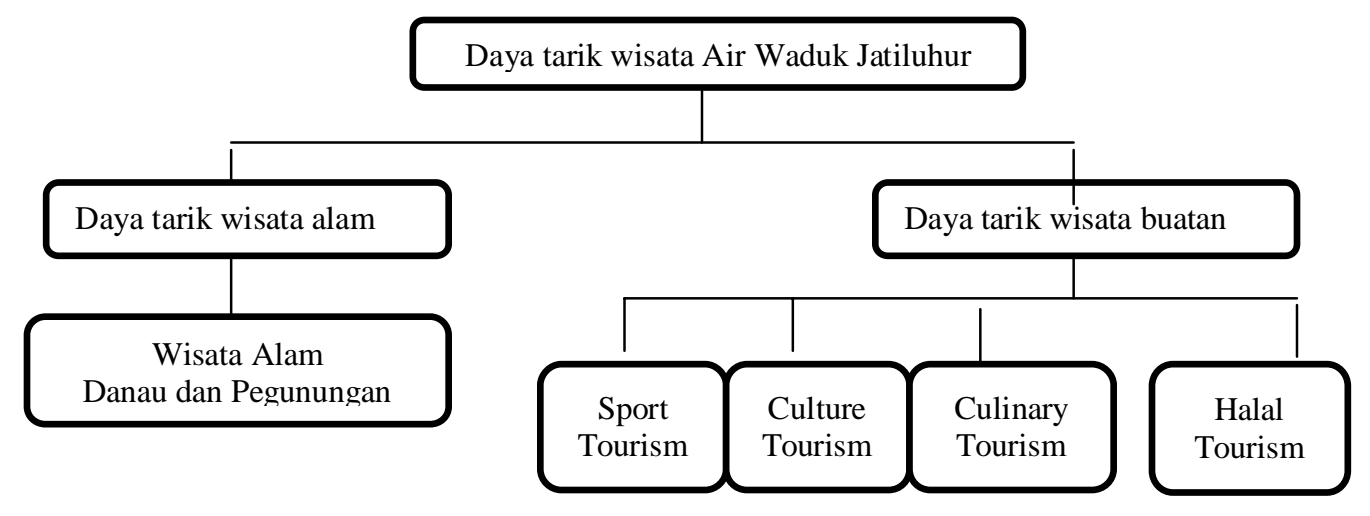

Bagan 1. Daya Tarik Waduk Jatiluhur

Sumber: Observasi Peneliti (2019) 
(Morgan, 2002) dalam Schaar (2013: 3) menyatakan bahwa untuk sebuah destinasi seperti wisata potensial, merek menjembatani kesenjangan antara aset yang diberikan dan persepsi pengunjung. Qu (2011) dalam Schaar (2013: 3) menambahkan bahwa merek tujuan melayani dua fungsi utama: identifikasi dan diferensiasi. Seperti halnya merek produk tunggal, merek tujuan juga terdiri dari komponen kesadaran dan gambar. Seperti sebelumnya, kesadaran merek dianggap sebagai prasyarat untuk dimensi merek lainnya. Maka untuk mendapatkan identifikasi dan diferensiasi merek itu, pemerintah daerah menempatkan merek berdasarkan daya tarik yang dapat dikembangkan di waduk Jatiluhur. Keempat daya tarik wisata tesebut dapat menjadi sebuah identitas brand wisata yang memiliki diferensiasi yang ditawarkan oleh wisata waduk jatiluhur.

Brand waduk jatiluhur sebagai wisata air terbesar akan didukung dengan daya tarik jenis wisata yang ditawarkan. Pemerintah daerah mengharapkan wisatawan akan mengenal wisata air waduk jatiluhur dengan beberapa daya tarik wisata yang memiliki diferensiasi dengan wisata air lainnya di Jawa Barat.

\section{3) Brand Introduction}

Salah satu langkah penting untuk menciptakan destination branding adalah mengenalkan produk kepada masyarakat sebagai konsumen potensial dari destinasi wisata. Untuk memperkenalkan brand, pemasar destinasi perlu untuk melihat target wisatawan yang ingin dijangkau sebagai pasar potensial. Penggolongan wisatawan dapat setidaknya dapat dibagi menjadi wisatawan domestik atau wisatawan mancanegara. Weaver dan Lawton (2014: 23) menjelaskan bahwa jika perjalanan wisata terjadi di luar lingkungan seseorang biasa berakatifitas tetapi masih berada di dalam negara tempat ia tinggal, maka individu itu akan diklasifikasikan sebagai wisatawan domestik. Jika pengalaman itu terjadi di luar negara tempat tinggal, maka orang itu akan diklasifikasikan sebagai turis internasional atau wisatawan mancanegara. Aspek pariwisata internasional yang jarang diakui adalah fakta bahwa perjalanan wisata semacam itu selalu melibatkan pergerakan di dalam kepemilikan turis internasional suatu negara.

Dalam peluncuran dan memperkenalkan brand merupakan tahap mengkomunikasikan brand melalui berbagai media, baik secara online dan offline. Pemerintah provinsi Jawa Barat melakukan brand intriduction mengenai destinasi wisata dengan melakukan promosi wisata, salah satunya dengan event olahraga. Wisata olahraga atau sport tourism, menurut Dedi Taufik, akan menjadi daya tarik yang akan menarik wisatawan mancanegara. Warpani (2007) menjelaskan bahwa wisata olahraga adalah mengunjungi peristiwa di dunia olahraga. Dengan adanya event-event olahraga bertaraf internasional maka sekaligus dapat memperkenalkan wisata-wsiata lain yang dapat dinikmati oleh para atlet. The $1^{\text {st }}$ Jatiluhur Stand Up Paddle and Kayak Exhibition bertajuk "Green Water Life" pada tanggal 13-14 Juli 2019 menjadi salah satu sarana yang dilakukan pemerintah daerah untuk memperkenalkan wisata waduk Jatiluhur sebagai wisata air dengan sejumlah daya tarik brand yang berbeda. Acara The $1^{\text {st }}$ Jatiluhur Stand 
Up Paddle and Kayak Exhibition sukses terselenggara dan dirasakan pemerintah daerah meraih banyak perhatian para wisatawan. Acara yang diselenggarakan melalui kerjasama Perum Jasa Tirta II (PJT) dengan dinas kepariwisataan kabupaten Purwakarta. ditargetkan memiliki skala nasional dan internasional yang lebih besar di tahun 2020. Dengan adanya event-event seperti kompetisi olahraga dan pagelaran musik dan budaya maka pengenalan terhadap produk destinasi wisata akan menjadi lebih mudah. Karena dengan adanya event, maka secara tidak langsung akan mengenalkan lokasi dilakukannya event tersebut

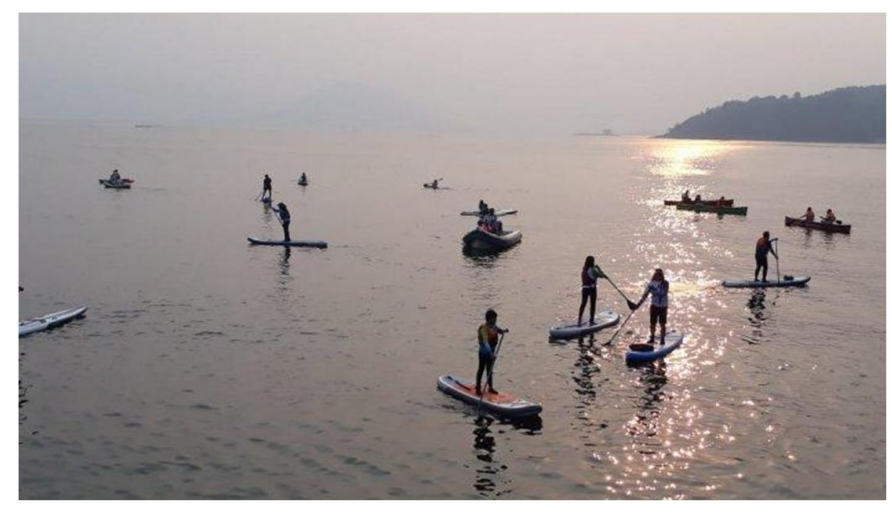

Gambar 4. Pemain Stand Up Paddleboard di Waduk Jatiluhur Sumber : Tribunjabar (2019)

Boo (2009) dalam (Wong et al., 2018). menyatakan bahwa pemasar destinasi harus mengembangkan kampanye yang menekankan karakteristik khas dan elemen menarik dari destinasi wisata. Nilai dari brand destinasi wisata berasal dari pengalaman yang dimiliki pelanggan di sana dan mengarah ke loyalitas pelanggan dan cara terbaik untuk meningkatkan ini adalah dengan mencari tahu apa yang konsumen anggap berharga kemudian mempromosikan fitur itu. Seorang pemasar perlu fokus pada pengalaman pengunjung secara keseluruhan juga, bukan hanya pengalaman dengan satu layanan atau produk tertentu di sebuah destinasi wisata.

Setelah adanya pengalaman terhadap destinasi wisata tersebut maka besar kemungkinan wisatawan akan kembali lagi atau bahkan mengajak kerabat mereka untuk mengunjungi lokasi tersebut bila pengalaman yang diberikan menjadi pengalaman yang positif. Untuk memberikan pengalaman yang positif kepada wisatawan, pemerintah daerah perlu memastikan setiap sarana dan prasarana ketika event tersedia dengan baik dan nyaman, serta adanya kesadaran bagi masyarakat untuk turut serta mempromosikan destinasi wisata dan juga memberikan pelayanan yang terbaik bagi wisatawan yang datang.

Selain kemampuan berwisata, pemasar destinasi wisata juga harus menarik minat dari wisatawan potensial. Dengan adanya pelayanan yang baik dan kepuasan pada pengunjung, maka diharapkan informasi akan tersebar dan menjadi sebuah promosi dari mulut ke mulut yang secara tidak langsung 
mengenalkan destinasi wisata. Gunn (1988) dalam Warpani (2007: 22) memandang bahwa pariwisata sebagai suatu sistem dan memilahnya dalam sisi permintaan dan sediaan. Komponen permintaan terdiri atas elemen orang, ditengarai oleh hasrat orang melakukan perjalanan dan kemampuan melakukannya, sedangkan komponen sediaan adalah daya tarik wisata, serta perangkutan, informasi dan promosi, dan pelayanan.

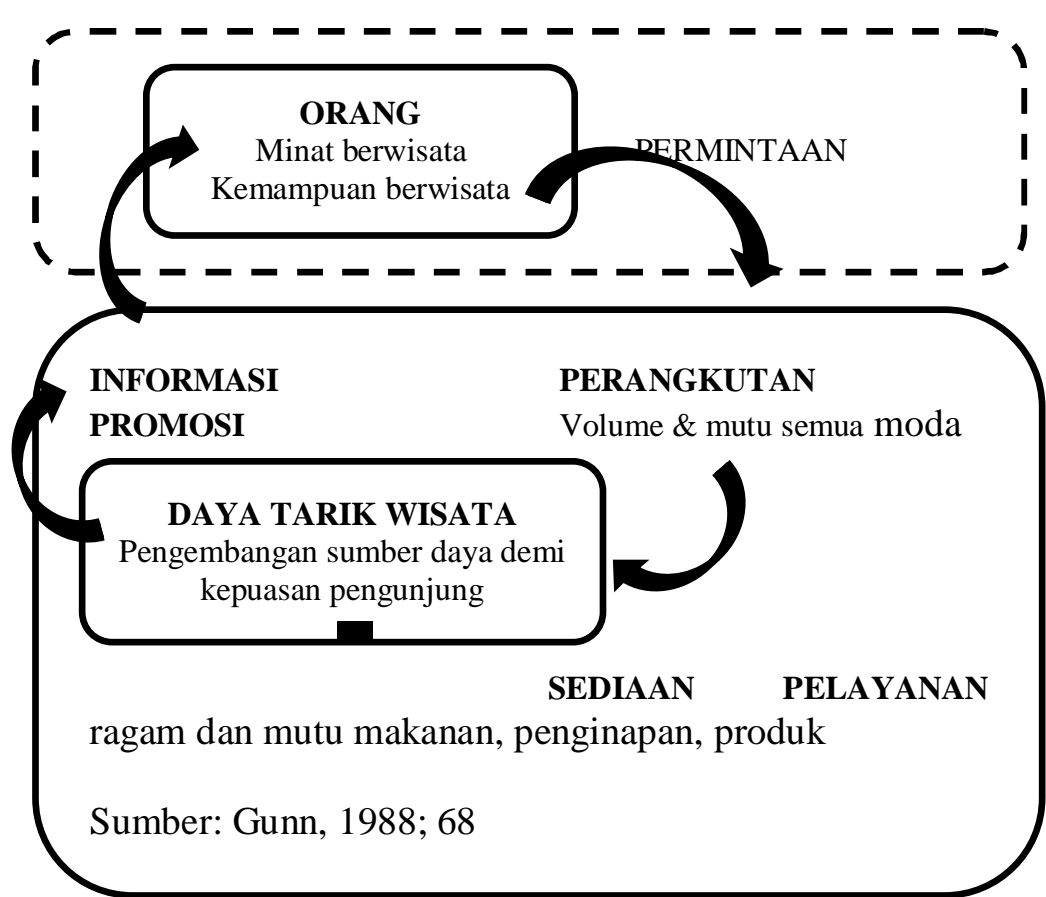

Model 1. Komponen fungsional kunci yang membentuk dinamika dan sistem hubungan kepariwisataan.

Sumber: Warpani, (2007: 22)

Weaver dan Lawton (2014: 23) mengungkapkan bahwa potensi pariwisata internasional berbeda dengani pariwisata domestik dalam beberapa hal. Pertama, dibandingkan dengan besarnya pariwisata internasional, wisatawan domestik jauh melebihi jumlah wisatawan internasional dalam skala global kecuali negara-negara miskin. Kedua, relatif sulit mengatur wisatawan domestik dibandingkan dengan wisatawan internasional, terlepas dari jumlah dan kepentingan ekonomi. Alasan lainnya adalah bahwa sebagian besar pemerintah tidak menganggap wisatawan domestik sebagai wisatawan potensial, karena mereka tidak membawa devisa yang sangat berharga ke negara. Seringkali jumlah wisatawan internasional menurun, pemerintah langsung diminta untuk mendukung bisnis pariwisata lokal dengan mempromosikan sektor pariwisata domestik

Menarik wisatawan mancanegara cenderung lebih mudah daripada menarik wisatawan domestik untuk berkunjung. Warpani (2007: 211) menjelaskan bahwa motivasi wisatawan mancanegara pada 
umumnya adalah berlibur menikmati iklim tropis. Wisatawan mancanegara biasanya ingin menikmati keindahan taman laut, keasyikan berselancar diayun-ayun ombak dan gelombang laut. Sebagian lagi berjalan-jalan melihat dan mengetahui kekhususan budaya dan penduduknya, adat istiadat, karya seni bangsa lain, dan memperluas pergaulan. Sedangkan pada wisatawan domestik di Indonesia, sulit untuk menentukan dan membaca minat wisatawan bila tidak ada daya tarik yang unik dan pengenalan wisata yang baik. Untuk memperkenalkan wisata waduk Jatiluhur, juga akan diadakan festival jazz jatiluhur di bulan September 2019. Dengan mengusung wisata berbasis air, sehingga para penonton nantinya akan menikmati perhelatan musik di atas air.

Selain melalui event-event, strategi yang dilakukan oleh pemerintah daerah juga dengan menginformasikan adanya destinasi wisata melalui sms blast. Kadisparbud Pemprov Jawa Barat Dedi Hidayat menjelaskan beberapa momentum atau peristiwa bisa menjadi sebuah peluang untuk memperkenalkan

\section{4) Brand Implementation}

Dalam sebuah penelitian yang dilakukan oleh Qu (2011) dalam beberapa penemuan memperlihatkan bahwa pentingnya masing-masing dimensi destination branding untuk konsumen. Ditemukan asosiasi atau atribut kognitif yang memiliki efek terkuat pada keseluruhan gambar, diikuti oleh dimensi 'gambar unik' dan kemudian oleh komponen afektif. Selain itu, pemasar harus berusaha untuk mengumpulkan data pengunjung keras seperti jumlah pengunjung yang berulang dan pertama kali(Wong et al., 2018). Morgan \& Pritchard (2004 : 61) destinasi wisata pada masyarakat. Momentum seperti arus mudik dan arus balik lebaran dimanfaatkan oleh pemerintah daerah untuk menyebarkan sms kepada para pemudik yang melewati jalur cipularang yang berisikan mengenai informasi destinasi wisata. Strategi tersebut dirasakan pemerintah daerah cukup efektif karena pemudik yang terjebak kemacetan ataupun pengalihan arus melalui Purwakarta cukup banyak yang akhirnya berkunjung ke destinasi wisata di Purwakarta.

Untuk pengenalan ke wisatawan mancanegara, pemerintah provinsi Jawa Barat berencana untuk melakukan promosi wisata di bandara-bandara nasional dan internasional dengan memasang spanduk atau poster "Selamat Datang di Jawa Barat" dengan menampilkan wisata-wisata unggulan termasuk wisata air waduk jatiluhur, meskipun lokasi bandara bukanlah di Jawa Barat. Menurut Dedi Hidayat, strategi tersebut sebagai upaya untuk memperkenalkan wisata Jawa Barat termasuk wisata air waduk jatiluhur.

berpendapat bahwa merek telah dikonseptualisasikan dalam empat cara utama, sebagai perangkat komunikasi, entitas persepsi, penambah nilai dan hubungan. Secara garis besar, dalam istilah pemasaran merek mewakili kombinasi unik dari karakteristik produk dan ditambahkan nilai-nilai, baik fungsional dan nonfungsional, yang telah diambil pada yang relevan makna yang terkait erat dengan merek itu, kesadaran yang mungkin sadar atau intuitif. Keuntungan merek dijamin melalui komunikasi yang menyoroti manfaat spesifik suatu produk, yang berpuncak dalam kesan keseluruhan merek yang 
unggul. Gambar yang dihasilkan produk pikiran konsumen, bagaimana posisinya, sangat penting untuk keberhasilan utamanya (Kotler \& Gertner, 2002)

Branding merupakan bentuk komunikasi yang dimanfaatkan sebagai pembeda sebuah produk. Dalam destination branding yang dibedakan adalah kekhasan tempat wisata itu tersendiri. Banyaknya tempat wisata di Indonesia bahkan di Jawa Barat mengakibatkan daya saing antar destinasi wisata meningkat, tentu saja hal tersebut berdampak positif, karena semua pihak seperti pemerintah, dinas pariwisata setempat dan pihak pengelola akan memberikan perhatian yang lebih untuk memperbaiki lokasi tersebut. Dalam branding kawasan Jatiluhur, simbol atau slogan yang digunakan adalah d'Jatiluhur. Simbol d'Jatiluhur berada di kawasan istora tidak jauh dari pintu masuk wisata. Simbol d'jatiluhur, menurut Sekretaris Dinas Pariwisata, Kebudayaan, Pemuda, dan Olahraga Kabupaten Purwakarta, Heri Anwar, menjadi simbol sebagai penanda yang diharapkan dimanfaatkan wisatawan untuk simbol identitas wisata waduk jatiluhur yang tidak ditemukan di tempat lain

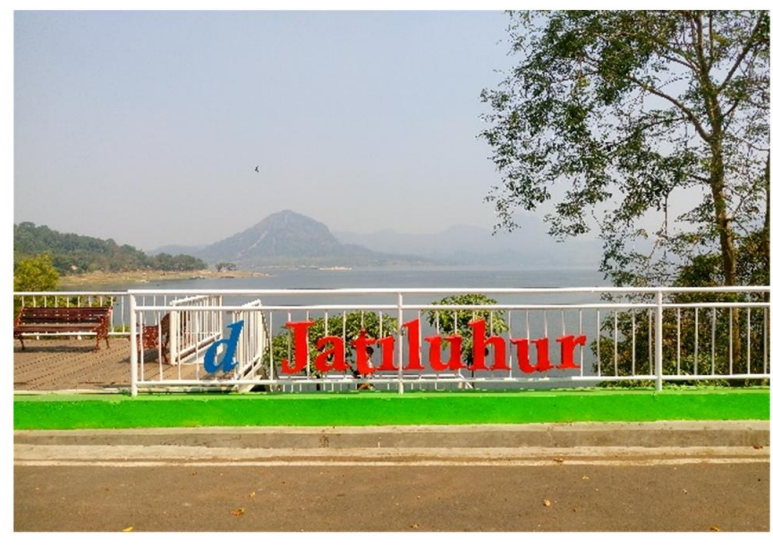

Gambar 5. Slogan Kawasan Waduk Jatiluhur Sumber : Dokumentasi Penulis (2019)

Melalui slogan d'Jatiluhur potensi wisata yang dimaksimalkan di Kawasan tersebut ialah branding sport tourism. Di era modern saat ini, wisata berbasis minat dan hobi banyak digemari oleh banyak kalangan. Sport tourism merupakan bentuk kegiatan olahraga yang dikombinasikan dengan promosi pariwisata. Secara historis waduk Jatiluhur dahulu sekali sudah dipakai olahraga ski air, jadi kekhasan waduk tersebut memang erat dengan olahraga air. Sehingga sudah tidak asing bagi waduk Jatiluhur untuk lebih mengeksplor potensi yang dimilikinya.

Berdasarkan branding dengan empat daya tarik yang di promosikan d'Jatiluhur, diharapkan itu semua dapat menawarkan nilai baru yang unik sekaligus khas bagi kawasan tersebut. Cara mengkomunikasikan nilai-nilai baru waduk Jatiluhur ialah dengan promosi. Sebuah teori dari Fill (2013) dalam Bungin (2015:70) menyampaikan bahwa ada triangulasi brand yang dapat digunakan yaitu brand promise, brand positioning dan brand perfomance. Bentuk triangulasi 
brand dapat digambarkan melalui ilustrasi di bawah ini :

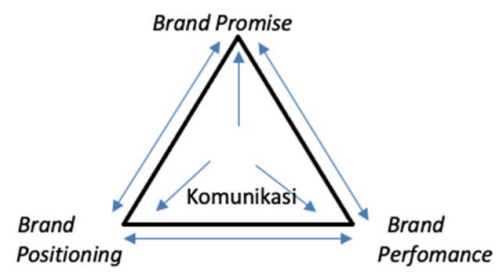

Gambar 6. Triangulasi Brand

Sumber : Bungin, (2015)

Positioning adalah rancangan yang dibuat oleh produsen untuk menciptakan kesan yang menarik dan mudah diingat oleh konsumennya. Positioning yang dirancang saat ini oleh waduk Jatiluhur adalah destinasi wisata air. Sebagai salah satu tempat yang sedang menjadi primadona pemerintah kabupaten Purwakarta. Wisata di Jatiluhur tidak hanya dari pemandangan bendungannya saja tapi wisatawan juga dapat melakukan permainan olahraga air seperti kayak dan paddle board, makan di restoran terapung dan menyaksikan acara musik di bendungan.

Memposisikan diri sebagai wisata destinasi air dengan berbagai pilihan wisata menarik didalamnya, waduk Jatiluhur menciptakan branding sebagai wisata air unggulan di Jawa Barat. Selain brand melalui positioning sebagai destinasi wisata air, brand waduk Jatiluhur juga perlu didukung brand performance seperti kegiatan yang bertaraf internasional, dan unik yang ada di kawasan tersebut, dan brand promise yang dijanjikan oleh pihak-pihak pendukung dan pengelola kawasan Jatiluhur. Dan itu semua didukung dengan strategi komunikasi sehingga brand akan tercipta dengan baik.

Mengenai brand performance, selain kegiatan wisatanya Pariwisata juga berkaitan dengan kepuasan pelanggan, karena kepuasan yang diterima pelanggan akan berdampak pada kemajuan dan perkembangan pariwisata tersebut. Dari hasil wawancara dengan sekretaris dinas pariwisata kabupaten Purwakarta, untuk mendukung brand performance ini mereka melakukan pelatihan sadar wisata, pada tahun ini pembinaan sadar wisata dilakukan di bulan Februari, Maret dan April. Pemerintah kabupaten Purwakarta membina masyarakat di masing-masing kecamatan, 17 kecamatan, sasarannya yang pertama pihak pengelola destinasi yang ada di kecamatan, yang kedua pemangku adat mulai dari RT RW, kemudian tokoh masyarakat, tokoh agama, tokoh sesepuh, tokoh pemuda, yang keempat camat dan kepala desa, keempat komponen ini dikumpulkan dalam satu kawasan, ada di kawasan destinasi, ada di kawasan kecamatan, untuk dibina dan diberi pelatihan bagaimana cara berkomunikasi dengan wisatawan yang datang di tempat wisata.

Brand promise. Yang dilakukan oleh pemerintah daerah dalam pengembangan wisata Jatiluhur ini dilakukan dengan cara kerjasama melalui pendekatan pentahelik, yaitu akademisi, pebisnis, dunia usaha, dana-dana CSR, dana umat dan sebagainnya. Pihak PJT II, BUMN, BUMD dan Pemerintah kabupaten 
Purwakarta dalam hal ini melakukan koordinasi untuk sama-sama mendukung potensi waduk Jatiluhur, mulai dari perbaikan dan promosinya. Bentuk perkembangan yang dijalankan salah satunya ialah dengan memperbaiki kawasan waduk agar bersih dan bebas dari hama dari eceng gondok dengan merekrut sukarelawan-sukarelawan untuk membersihkan Jatiluhur. Lalu pihak pemerintah juga melakukan komunikasi dengan pemilik untuk mengatur mekanisme penggunaan jaring apung agar ideal dan rapih di Jatiluhur.

Prebensen (2007) menjelaskan bahwa langkah penting untuk menciptakan destination branding yang kuat dan terpadu adalah mendapatkan kerja sama dan kolaborasi dari berbagai kelompok pemangku kepentingan. Memahami hubungan antara kelompok-kelompok pemangku kepentingan ini dan nilai setiap kontribusi untuk merek akan membantu dalam menciptakan dan mencapai persetujuan pada strategi branding (Wong et al., 2018). Bersama dengan para pengunjung, masyarakat setempat dan pemilik bisnis adalah fitur utama dari inti merek. Dalam menghasilkan destination branding, sangat penting untuk menjaga nilai-nilai dalam pemikiran pemangku kepentingan, terutama penduduk setempat, saat mereka mewujudkan destination branding. Prebensen (2007) dalam
(Wong et al., 2018) menyatakan bahwa sangat penting untuk mendapatkan persetujuan dan sikap mendukung dari masing-masing pendukung destinasi pariwisata seperti hotel, masyarakat sekitar, dan sebagainya.

Pemerintah daerah bekerja sama dengan para pemangku kepentingan dalam perekonomian seperti hotel dan restoran untuk bekerja sama meningkatkan pariwisata dengan menerapkan pengintegrasian wisata. Untuk melengkapi brand wisata air waduk jatiluhur, maka hotel-hotel di Purwakarta untuk memperkenalkan dan menawarkan paket wisata lengkap seperti paket penginapan, tranportasi, dan kuliner sehingga memudahkan wisatawan.

Pemerintah daerah selain melalui branding secara offline juga melakukan pemasaran wisata melalui online yakni membuat sebuah aplikasi bernama "Sampurasun". Sampurasun merupakan aplikasi original yang diciptakan oleh Dinas Pariwisata, Kebudayaan, Pemuda dan Olahraga Kabupaten Purwakarta yang berfungsi sebagai penyedia informasi kepada wisatawan mengenai destinasi wisata, kuliner, events, tempat ibadah hingga rute angkutan umum. Tidak hanya berisikan informasi, dalam aplikasi sampurasun juga memiliki beberapa fitur yang dapat dimanfaatkan oleh wisatawan, seperti fitur untuk memesan ojek, menelpon polisi, pemadam kebakaran, dan ambulan 

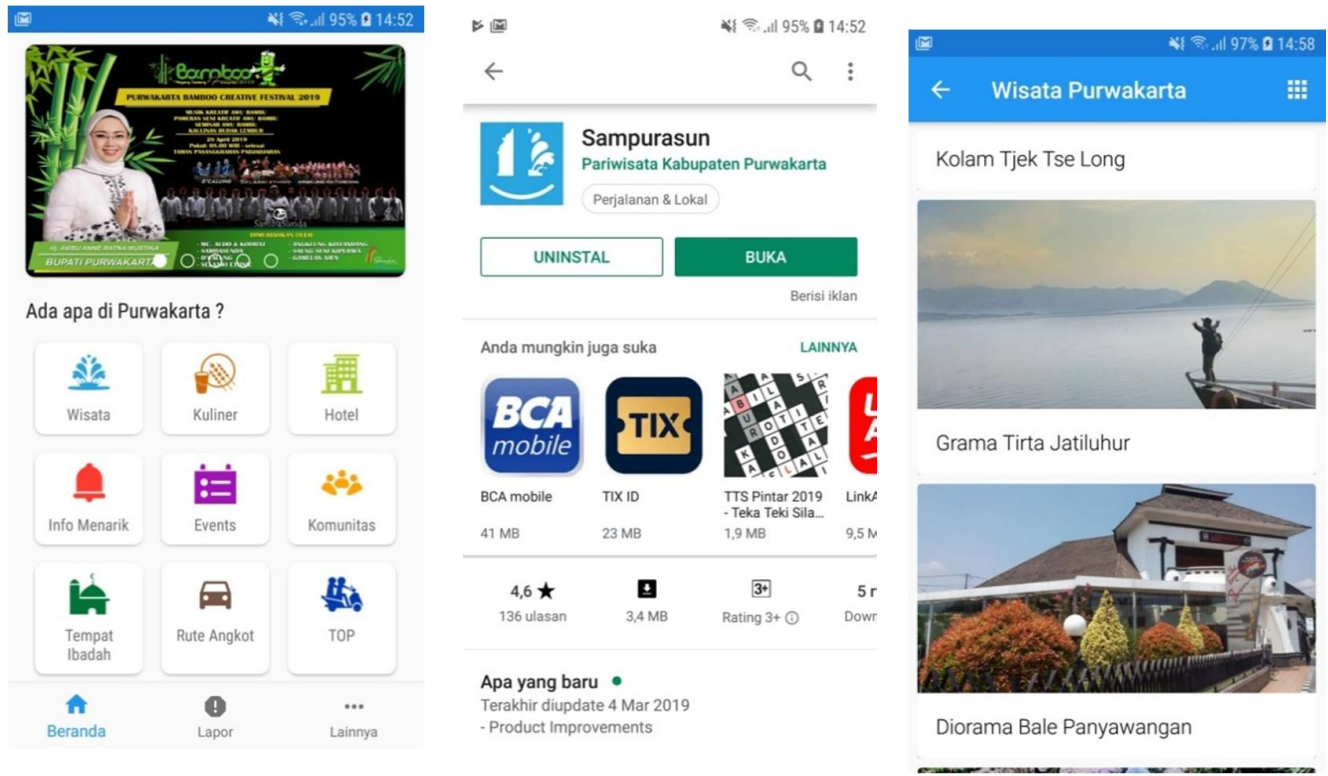

Gambar 7. Aplikasi Wisata "Sampurasun"

Sumber: Dokumentasi Penulis (2019)

\section{5) Monitoring and Evaluation}

Tahap terakhir menurut Morgan \& Pritchard (2004) dalam mengelola destination branding adalah memantau apakah ada penyimpangan, kekurangan dan sebagainya dari apa yang telah dilakukan. Hasil monitoring tersebut kemudian dievaluasi sebagai perbaikan untuk mencapai tahapan brand pada produk destinasi wisata. Boo (2009) mengungkapkan bahwa image sebuah destinasi terikat sangat erat dengan brand destination dan konsumen mendapatkan informasi tentang suatu tempat dari berbagai sumber. Penting untuk mengetahui persepsi apa yang sudah dimiliki tentang destinasi. Penting juga bagi seorang pemasar untuk mendapatkan wawasan tentang pentingnya target pasar yang ditempatkan pada berbagai komponen identitas merek karena itu akan memungkinkan bila pengelola destinasi untuk meningkatkan arti- penting dari atribut yang ada paling relevan bagi konsumen. Riset pasar memperhatikan aspek tujuan mana yang harus difokuskan dalam komunikasi pemasaran (Wong et al., 2018)

Untuk melakukan monitoring, pemerintah daerah mengaku melakukan beberapa cara. Salah satu cara yakni dengan indikator kunjungan wisatawan. Seperti halnya jumlah penjualan dalam sebuah produk, jumlah kunjungan wisatawan di destinasi wisata menjadi indikator bila brand destinasi wisata tersebut mengalami penurunan atau peningkatan.

Selain melalui indikator pengunjung destinasi wisata, pemerintah daerah melakukan evaluasi melalui komunitas. Gartner (2011) menunjukkan bahwa setiap kelompok mengevaluasi destination branding agak berbeda. Dengan informasi tentang tingkat kunjungan 
pertama dan berulang, seorang pemasar dapat menyesuaikan strategi pemasaran mereka sesuai untuk fokus pada menjangkau kelompok tertentu (Wong et al., 2018).

Melalui kegiatan bersama komunitas, menurut Sekretaris Dinas Pariwisata, Kebudayaan, Pemuda, dan Olahraga Kabupaten Purwakarta, Heri Anwar, pemerintah daerah dapat memantau bila ada pelayanan yang kurang memuaskan untuk pengunjung. Komunitas yang digandeng bersama pemerintah juga bukanlah komunitas yang sembarangan, namun komunitas yang memiliki visi dan misi yang seiringan dengan visi misi pariwisata pemerintah daerah. Pemerintah pun berupaya untuk mencoba merangkul komunitas-komunitas olahraga untuk meningkatkan promosi dan menguatkan branding wisata waduk jatiluhur.

Selain dengan aplikasi, pemerintah daerah juga memiliki tim media sosial yang dikelola oleh Dinas Pariwisata, Kebudayaan, Pemuda dan Olahraga Kabupaten Purwakarta. Tim media sosial berisikan para pegawai outsourcing yang dikontrak dan diberikan pelatihan untuk melakukan monitoring media sosial. Melalui pemantauan di media sosial, pemerintah dapat melihat keefektifan branding dipakai dan digunakan oleh netizen, seperti pengunggahan foto berlatar belakang waduk jatiluhur, tanggapan mengenai event-event yang dilakukan pemerintah, bahkan sampai merancang respon positif dan mengcounter respon negatif mengenai brand wisata waduk jatiluhur.

Setelah melakukan monitoring dan evaluasi maka penentuan destination branding dengan melakukan langkah-langkah strategis berikutnya untuk meningkatkan branding wisata waduk jatiluhur Untuk melakukan destination branding yang tepat maka triangulasi brand harus dilakukan secara tepat dengan melakukan peningkatan brand promise dan brand performance sesuai dengan positioning destinasi wisata. Untuk menjadi destinasi wisata unggulan, salah satu hal yang paling penting untuk dilakukan adalah ketersediaan askses yang memadai untuk dijangkau oleh calon wisatawan.

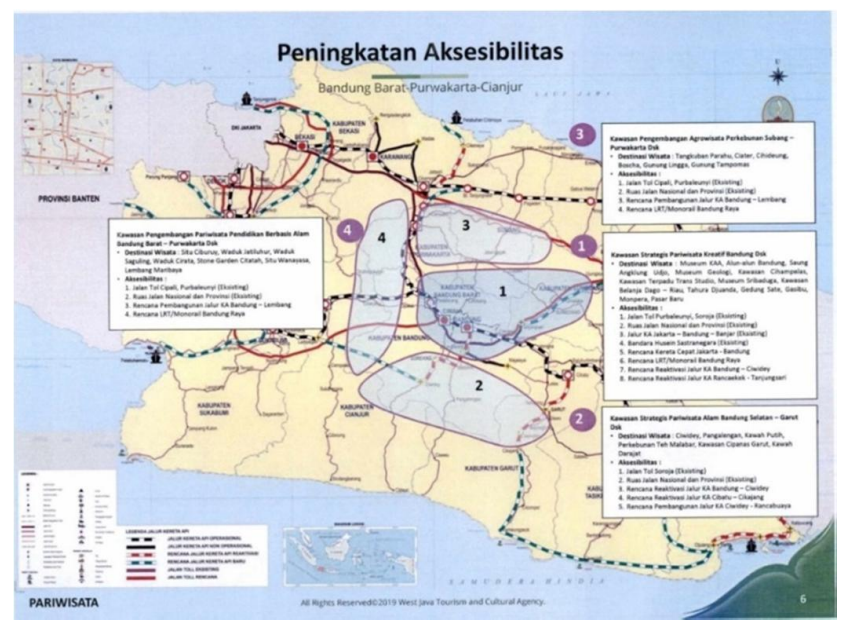

Gambar 8. Peningkatan Aksesbilitas Wisata Jawa Barat Sumber: Dokumen Disparbud Jawa Barat (2019) 


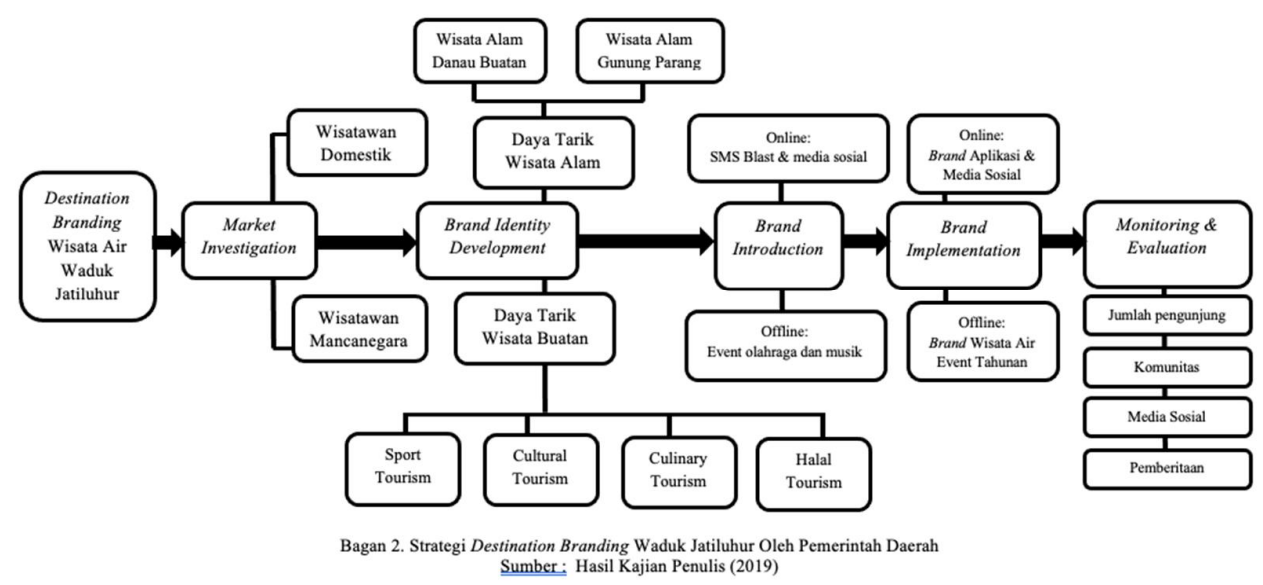

Strategi Branding dari setiap masing-masing daya tarik wisata buatan

Tabel 1. Tabel Tahapan Destination Branding Berdasarkan Daya Tarik Wisata Buatan

\begin{tabular}{|c|c|c|c|c|}
\hline & Sport Tourism & Cultural Tourism & $\begin{array}{l}\text { Culinary } \\
\text { Tourism } \\
\end{array}$ & Halal Tourism \\
\hline $\begin{array}{l}\text { Market investigation, } \\
\text { strategic analysis }\end{array}$ & $\begin{array}{l}\text { Target Pasar } \\
\text { Mancanegara } \\
\text { memiliki minat } \\
\text { pada olahraga } \\
\text { ekstrem }\end{array}$ & $\begin{array}{l}\text { City Branding } \\
\text { Kabupaten } \\
\text { Purwakarta } \\
\text { berhasil karena } \\
\text { mengedepankan } \\
\text { budaya sunda }\end{array}$ & $\begin{array}{l}\text { Pasar milenial } \\
\text { yang menyukai } \\
\text { wisata kuliner }\end{array}$ & $\begin{array}{l}\text { Permintaan } \\
\text { pasar terhadap } \\
\text { destinasi halal } \\
\text { yang nyaman } \\
\text { Jawa barat } \\
\text { salah satu } 10 \\
\text { destinasi halal } \\
\text { unggulan di } \\
\text { Indonesia }\end{array}$ \\
\hline $\begin{array}{l}\text { Brand identity } \\
\text { development }\end{array}$ & $\begin{array}{l}\text { Wisata } \\
\text { Olahraga Air }\end{array}$ & $\begin{array}{l}\text { Identitas budaya } \\
\text { Sunda dan } \\
\text { khususnya budaya } \\
\text { masyarakat } \\
\text { Purwakarta seperti } \\
\text { budaya Nyi Pohaci } \\
\text { Sang Hyang Sri }\end{array}$ & $\begin{array}{l}\text { Kuliner air } \\
\text { tawar dan } \\
\text { restoran } \\
\text { terapung }\end{array}$ & $\begin{array}{l}\text { Lokasi wisata } \\
\text { bersih dan } \\
\text { nyaman } \\
\text { beribadah }\end{array}$ \\
\hline Brand introduction & $\begin{array}{l}\text { Penyelenggaraa } \\
\text { n Event } \\
\text { olahraga } \\
\text { nasional dan } \\
\text { internasional } \\
\text { seperti Jatiluhur } \\
\text { Stand Up } \\
\text { Paddle and } \\
\text { Kayak Board } \\
\text { Exibition dan } \\
\text { Jatiluhur Run } \\
10 K\end{array}$ & $\begin{array}{l}\text { Pementasan } \\
\text { Pagelaran Budaya } \\
\text { Sunda dan Jatiluhur } \\
\text { Jazz Festival } \\
\text { sebagai event } \\
\text { budaya }\end{array}$ & $\begin{array}{l}\text { Jatiluhur Jazz } \\
\text { Festival } \\
\text { sekaligus } \\
\text { mengenalkan } \\
\text { kuliner jatiluhur } \\
\text { di tengah } \\
\text { danau. }\end{array}$ & $\begin{array}{l}\text { Pengenalan } \\
\text { wisata halal } \\
\text { dalam event- } \\
\text { event }\end{array}$ \\
\hline
\end{tabular}




\begin{tabular}{|l|l|l|l|l|}
\hline & & & & \\
\hline Brand implementation & $\begin{array}{l}\text { Penyelenggaraa } \\
\text { n event } \\
\text { olahraga } \\
\text { tahunan }\end{array}$ & $\begin{array}{l}\text { Pelatihan } \\
\text { masyarakat } \\
\text { Purwakarta untuk } \\
\text { sadar wisata dan } \\
\text { me }\end{array}$ & $\begin{array}{l}\text { Restoran } \\
\text { Terapung di } \\
\text { tengah danau }\end{array}$ & $\begin{array}{l}\text { Pelayanan toilet } \\
\text { bersih dan } \\
\text { tempat ibadah } \\
\text { yang memadai } \\
\text { dan bersih }\end{array}$ \\
& & & \\
\hline
\end{tabular}

\section{Simpulan}

Dalam penelitian ini ditemukan bahwa strategi destination branding yang dilakukan pemerintah daerah (baik pemerintah provinsi Jawa Barat dan pemerintah Kabupaten Purwakarta) sedang berjalan dengan melakukan beberapa langkah strategis, termasuk dalam penentuan brand waduk Jatiluhur yang akan diperkenalkan kepada masyarakat. Selain daya tarik alam buatan, tiga daya tarik buatan yang disusun dan dirancang oleh pemerintah daerah sebagai bagian dalam brand wisata waduk Jatiluhur perlu direalisasikan dan terus diawasi secara berkala agar brand sebagai wisata air unggulan di Jawa Barat tidak hilang dan tenggelam. Daya tarik wisata dapat menjadi penguat brand dengan rancangan buatan dan kerjasama pemerintah daerah.

Pengenalan brand wisata air di waduk Jatiluhur dilakukan melalui beberapa strategi kreatif dengan penggunaan sms blast dan pembuatan aplikasi wisata. Pemaksimalan aplikasi dan tim media sosial yang dikelola pemerintah perlu ditingkatkan dan dirancang secara

\section{Daftar Pustaka}

Azhari, Astrid Benedita, dkk. (2018). Analisis Proses Branding Kabupaten Purwakarta Branding Process Analysis Of Purwakarta Regency, Vol.5, No.1 Maret 2018.

Bakti, Agung Sarasa, (2019. Juni 14). Pemberitaan tentang Waduk Jatiluhur Bakal Dikembangkan spesifik untuk destinasi wisata tertentu, misalnya khusus untuk destinasi wisata waduk jatiluhur. Untuk mengembangkan brand dan memperluas produk daya tarik wisata melalui strategi penyelenggaraan event-event nasional dan internasional perlu dilakukan secara berkala dengan terus mengevaluasi pelayanan wisata termasuk bekerja sama dengan beberapa pemangku kepentingan, termasuk penyediaan sarana dan prasarana wisata halal. Pariwisata menjadi salah satu sektor yang sedang meningkat dan semakin besar pasarny. Pemerintah harus bisa melakukan branding wisata yang tepat sesuai sasaran dan daya tarik wisata di daerah tersebut dengan menggandeng para pemangku kepentingan dan masyarakat untuk peningkatan perekonomian daerah. Pemerintah pun harus berkomitmen penuh untuk terciptanya destination branding wisata di daerah-daerah yang berpotensi menarik wisatawan, tidak hanya dengan wisata alam tetapi dengan daya tarik buatan untuk menjangkau wisatawan domestik dan mancanegara.

Jadi Destinasi Wisata Air Unggulan. Diakses dari: https://jabar.sindonews.com/read/ 7867/1/waduk-jatiluhur-bakaldikembangkan-jadi-destinasiwisata-air-unggulan1560517569. 
Cai, L.A. (2002). Cooperative Branding for Rural Destination. Annals of Tourism Research 29(3): 720742.

Emrizal. (2016). Destination Branding Dalam Strategi Pemasaran Destinasi (Sebuah Tinjauan Teoritis), Polibisnis, Volume 8 No.2 Oktober 2016.

Kusuma, R. H. (2018). Analisis Potensi dan Pengembangan Desa Wisata di Kabupaten Sleman. Program Studi Geografi, Universitas Gadjah Mada.

Kusumah, S. A., \& Amaliah, I. (2015). Eksternalitas Waduk Jatiluhur Bagi Masyarakat Kecamatan Jatiluhur Kabupaten Purwakarta 1 1,2,3. 2015-2018.

Kotler, P., \& Gertner, D. (2002). Country as brand, product, and beyond: A place marketing and brand management perspective. Journal of Brand Management, 9(4), 249-261. https://doi.org/10.1057/palgrave.b m. 2540076

Peraturan Daerah No 15 tahun 2015 Tentang rencana induk pembangunan Kepariwisataan Provinsi Jawa Barat tahun 20152025. Bandung : Disbudpar Jawa Barat

Rahman, Ridhi \& Naili Farida. (2017). Pengaruh Destination Branding Dan Produk Wisata Terhadap Niat Berkunjung Kembali Melalui Word Of Mouth (Studi Kasus Pada Objek Wisata Alam Goa Kreo Semarang). Diponegoro Journal Of Social And Political Tahun 2017, Hal 1$7 . \quad \mathrm{http} / / /$ ejournals1.undip.ac.id/index.php/

Reisha, Tia, (2019. Juni 27). Pemberitaan tentang Beragam Program Pariwisata Dongkrak Pendapatan Asli Daerah. Diakses dari

https://travel.detik.com/travelnews/d-4602950/beragamprogram-pariwisata-dongkrakpendapatan-asli-daerah
Richelieu, Andre. (2018). A sportoriented place branding strategy for cities, regions and countries. ISSN: 2042-678X

Maruto, Nurul Aini $R$ dan Anam Miftakhul Huda, (2020). Destinasi Branding Kampung Lawang Seketeng Sebagai Wisata Kuliner. Jurnal Ilmiah Komunikasi Makna Vol.8,No.2, Agustus 2020, pp.118133

Maulida, Desi. (2019). Tourism Destination Branding: Analisis Strategi Branding Wisata Halal "The Light Of Aceh". Jurnal.utu.ac.id

Moleong, Lexy J. (2004). Metodologi Penelitian Kualitatif. Bandung: PT. Remaja Rosdakarya

Morgan, Nigel and Annette Pritchard. (2004). Destination Branding: Creating the Unique Destination Proposition. Oxford: Elsevier Butterworth-Heinemann Tersedia dari:https://www.researchgate.net/p rofile/David_Gertner/publication/2 33497710_Country_as_Brand_Prod uct_and_Beyond_A_Place_Marketi ng_and_Brand_Management_Persp ective/links/53d933590cf2631430c 3b208/Country-as-Brand-Productand-Beyond-A-Place-Marketingand-Brand-ManagementPerspective.pdf

Michandani, Eka Siti dan I Nyoman Sukma Arida. (2019). Perancangan Destination Branding Desa Wisata Kerta di Kecamatan Payangan Kabupaten Gianyar. Jurnal Destinasi Pariwisata Vol. 7 No 1, 2019.

Peraturan Daerah No 15 tahun 2015 Tentang rencana induk pembangunan Kepariwisataan Provinsi Jawa Barat tahun 20152025. Bandung : Disbudpar Jawa Barat

Warpani. Suwardjoko \& Indira Warpani. (2007). Pariwisata Dalam Tata Ruang Wilayah. Bandung: ITB 
Weaver, Dave \& Laura Lawton. (2014).

Tourism Management. Australia: John Wiley \& Sons Australia, Ltd

ANALYSIS OF TOURISM

DESTINATION BRANDING

STRATEGY FOR SABAH ,

MALAYSIAN BORNEO . Name:

Wong Siao Fui Institution: Kotler, P., Sanctis, M. P. De, Sartori, A., ... White, R. (2018). A Content Analysis of Tourism Destination Branding Strategy for Sabah, Malaysian Borneo ( 1 ) TITLE: A CONTENT Universiti Malaysia Sabah . Journal of Vacation Marketing, 2015 (November 2015), 327-340. https://doi.org/10.1177/135676671 2459689 